Article

\title{
The Resilience Capabilities of Yumcha Restaurants in Shaping the Sustainability of Yumcha Culture
}

\author{
Shanshan Dai, Qingming Cui * and Honggang Xu \\ School of Tourism Management, Sun Yat-sen University, Guangzhou 510275, China; \\ daishsh3@mail.sysu.edu.cn (S.D.); xuhongg@mail.sysu.edu.cn (H.X.) \\ * Correspondence: cuiqm7@mail.sysu.edu.cn
}

Received: 21 August 2018; Accepted: 13 September 2018; Published: 15 September 2018

check for updates

\begin{abstract}
This study investigates the sustainability of food heritage in the modern world. The city of Guangzhou in Guangdong province has quickly changed to become a large metropolis within 40 years after China's opening policy. Using Guangzhou's Yumcha heritage as the case, we propose that Yumcha restaurants' resilience has enhanced Yumcha heritage sustainability, and their dynamic capabilities have had a positive influence on both Yumcha restaurants' resilience and the sustainability of Yumcha heritage. The study focuses on (1) the influence of social-cultural changes on the sustainability of Yumcha culture, (2) the influence of restaurant dynamic capabilities on Yumcha heritage sustainability, (3) Yumcha restaurants' resilience-mediating effect, and (4) the moderating effects of social-cultural changes. The findings contribute to our understanding from four aspects: (1) Social-cultural changes negatively impact on Yumcha heritage; (2) the dynamic capability of Yumcha restaurants has a direct positive impact on Yumcha heritage; (3) the dynamic capabilities of Yumcha restaurants and social-cultural changes enable Yumcha heritage to become more resilient and improve the sustainability of Yumcha heritage; and (4) social-cultural changes moderate the indirect effects of proactive behavior on Yumcha heritage sustainability via Yumcha restaurant resilience.
\end{abstract}

Keywords: food heritage; restaurants' resilience; business resilience; sustainable local heritage; proactive uncertainty management

\section{Introduction}

This article explores the social and cultural factors that may affect local food heritage and how local food heritage copes with these changes and becomes more resilient. In an era of globalization, urbanization, and mobility [1], local and traditional culture faces multiple shocks caused by social and cultural changes [2]. How to protect local cultural heritage in the modern world is a major challenge [3]. Food represents a kind of cultural heritage. Food is not only associated with providing physical nutrition for humans, but it is also a marker of local culture [4-8].

Disruptions from the modern world to food heritage are enormous [3]. Why and how are some food heritages reserved, thriving, and emerging as more sustainable? This study uses Yumcha (饮茶) heritage as an example to examine how local heritage can be conserved sustainably and how it becomes resilient in the fast-changing modern world. Yumcha, of which the literal translation is 'drinking tea', originated in the Qing Dynasty. In this practice, people not only drink tea but also eat dim sum [9]. In 2007, Yumcha culture was designated as one of the intangible cultural heritages of Guangzhou [10]. Although experiencing many challenges and strikes, Yumcha is still popular in Guangdong province and surrounding regions, such as Guangxi province and Hong Kong [11]. Thus, Yumcha is a good example to illustrate the resilience of food heritage.

Several scholars have studied the sustainability of local cultural heritage. Related studies have mainly focused on general cultural heritage [3]. Main research topics involve the demand side, such as 
food-consumption changes and consumers' value changes [3]. However, enterprises, as the main carriers of local heritage, are seldom investigated. Specifically, in the food-heritage context, restaurants have considerable influence on the survival of food heritage.

From an enterprise perspective, the question remains on how food heritage can become resilient in encounters with different types of disruptions in modern cities. Little research has explored the sustainability of local food heritage from restaurant studies, with some exceptions. For example, Larsson et al. investigated the resilience of a nonprofit firm in promoting a local food system [12]. Research on restaurants has focused more on restaurant innovation [13]. Some studies have explored the paradox between authenticity and standardization of restaurants [14]. There is always a tension between commodification and heritage preservation [15]. Business and commercialization are usually thought of as causing negative effects on the authenticity of cultural heritage [16,17]. However, the positive effects of the resilience of restaurants in building sustainable food heritage when facing disruptions and opportunities in the modern world have not been examined. This study attempts to prove that successful businesses could also contribute to the sustainable development of cultural heritage.

When referring to enterprise resilience, recent research has paid more attention to the dynamic capabilities of enterprises [18]. Dynamic capabilities are a firm's high-level capabilities. However, it is complicated to reveal the relationship between resilience and dynamic capabilities. Specifically, in the context of local food-heritage sustainability, which kind of dynamic capabilities enhance restaurant resilience and, thus, food-heritage sustainability, and how?

This paper empirically analyzes the sustainability of Yumcha heritage when facing disruptions and opportunities in a changing social-cultural metropolitan city. Based on resilience theory, following a dynamic-capabilities perspective [19], this study tries to reveal how specific dynamic capabilities, such as restaurant innovation and disruption orientation, influence Yumcha restaurants' resilience and, in turn, the sustainability of Yumcha heritage.

\section{Literature Review}

In this study, we postulate that a Yumcha restaurant with high dynamic capacity enhances its resilience to disruptions and, in turn, enhances the sustainable conservation of Yumcha culture. The level of disruption the firm faces may moderate this effect. The conceptual model is illustrated in Figure 1.

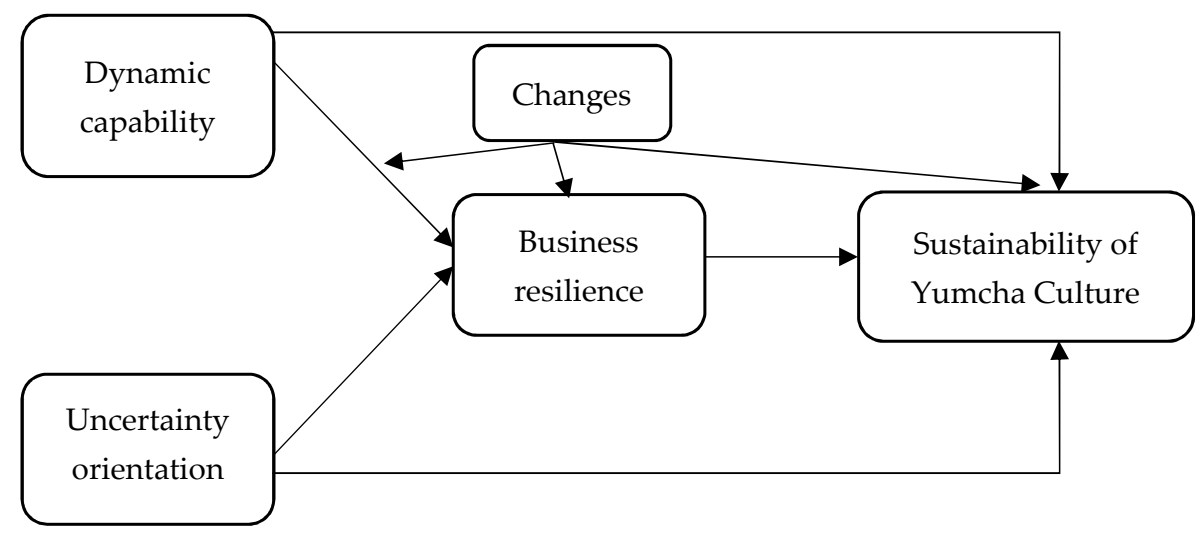

Figure 1. Conceptual model of this study.

\subsection{Restaurant Resilience and Local Food-Heritage Sustainability}

Sustainable development is defined as "development that meets the needs of the present without compromising the ability of future generations to meet their own needs" [20] (p. 43). Throsby revealed that cultural sustainability includes the preservation of cultural valuations and cultural activities for 
the next generations [21]. The sustainability of food heritage should be based on the protection of dining activities and food cultural valuations.

The sustainability of cultural heritage relates closely to its instrumental value as a driver in developing the economy, creating jobs, and eliminating poverty [22,23]. The development of Yumcha restaurants plays a crucial role in the preservation of Yumcha food heritage. In a world full of change and uncertainty, only when restaurants are resilient can they keep providing Yumcha services and promoting the values behind the activity.

Recent studies of resilience have shifted from exploring ecological resilience to investigating social resilience [24,25], including firm resilience. Roundy, Brockman, and Bradshaw defined firm resilience as a firm's capability to recover from and adapt to shocks and disruptions [26]. Within the context of Yumcha culture, we focused on restaurants where customers can enjoy the Yumcha experience. The Yumcha experience is complex. People drink tea, eat dim sum, chat with others, and communicate with employees. Traditionally, people can drink tea and eat dim sum from morning until night. However, in modern times, the culture has shrunk to some degree; today, only the practice of drinking "morning tea" exists widely. In fact, many restaurants in Guangzhou only provide morning-tea services. Thus, this article focuses on morning-tea restaurants to explore the strikes to and the resilience of local food heritage. We define restaurant resilience as the general morning-tea restaurant's ability to be flexible, bear pressure, and recover from and adapt to shocks and disruptions. Thus, we hypothesize:

Hypothesis 1 (H1). Yumcha restaurant resilience positively affects the sustainability of Yumcha culture.

\subsection{Dynamic Capability}

Dynamic capability has only recently been developed as a perspective from which to view resilience [27]. Van de Vegt et al. noted that "to identify the capabilities of the system, and to understand how they communicate with others and with their environment, is important to understand a system's resilience and to predict key performance outcomes" [27] (p. 973). Dynamic capabilities are essential to a system's (within this food-heritage context, the morning-tea restaurant) adaptation process and therefore the sustainability of Yumcha culture. Thus, we can assume that dynamic capabilities positively affect Yumcha restaurants' resilience, dynamic capabilities have a positive impact on the sustainability of Yumcha culture, and dynamic capabilities have an indirect positive effect on Yumcha heritage sustainability via Yumcha restaurant resilience.

Dynamic capability refers to that firm that has the capacity to "integrate, build, and reconfigure internal and external competences to address rapidly changing environments" [19] (p. 516). Dynamic capabilities have many characteristics: (1) generate organizational learning, (2) produce new incorporations of assets, and (2) update operational (or ordinary) capabilities [28,29].

As dynamic-capability research is quite new, researchers have explored the meaning of dynamic capability from diverse perspectives. Based on the characteristics of capacity, dynamic capacities include three dimensions: sensing, seizing, and reconfiguring [30]. Based on the characteristics of response behavior, Parker and Ameen explored dynamic capacities from the following aspects: disruption orientation, investment in risk-prevention infrastructure, resource reconfiguration, and proactive risk management [18]. The context of the Yumcha restaurant is relatively narrow and concrete. The dynamic capacities for a restaurant to survive in a changing social-cultural world include two dimensions, uncertainty orientation and proactive behavior.

\subsubsection{Uncertainty Orientation}

Uncertainty orientation helps to enhance firms' ability to identify disruptions and opportunities. It serves as a kind of sensing capability [30], monitoring external social-cultural changes, interpreting 
the potential impact, and searching for and identifying market opportunities. Research has explored disruption orientation to immediate shocks.

Disruption orientation refers to "when the business environment is full of uncertainty, a firm's general consciousness and awareness of, concerns about, seriousness toward, and recognition of the opportunity to learn from a broader range of disruptions" [18] (p. 873). Within the Yumcha context, disruption may refer not only to immediate shocks but also to gradual social-cultural changes [25]. The concept of uncertainty orientation measures an adaptation to a broader range of uncertainty, including both disruption and opportunities that affect the firm. It is more possible for firms with an uncertainty orientation to become resilient during disruptions. Thus, we suggest:

Hypothesis 2 (H2a). Uncertainty orientation has a positive relationship with resilience.

Hypothesis $2(\mathrm{H} 2 \mathrm{~b})$. Uncertainty orientation has a positive relationship with sustainability of Yumcha culture.

\subsubsection{Proactive Behavior}

After identifying disruptions and opportunities, firms need to implement proactive behaviors to respond to disruptions and to seize opportunities. Proactive behavior measures a firm's actions to create value from external opportunities, make new strategies, and adjust business models and value chains [31]. Proactive behaviors also refer to behaviors to orchestrate firms' asset base, process innovative valuable combinations, and learn to build creative capabilities [30]. Within this study's context, proactive behavior is defined as the behavior to reconfigure resources in response to uncertainties. Active Yumcha restaurants would need to constantly be vigilant with regards to external social-cultural changes, and respond actively to potential disruptions and opportunities, seizing the time and resources to learn and to accumulate knowledge from past experience and grabbing opportunities [18]. Thus, we give the following hypotheses:

Hypothesis 3 (H3a). Proactive behavior has a positive relationship with resilience.

Hypothesis $3(\mathrm{H} 3 b)$. Proactive behavior has a positive relationship with the sustainability of Yumcha culture.

Proactive behaviors in the restaurant industry mainly stem from innovation, including product innovativeness, service innovativeness, technological innovation, environmental innovation, and experiential innovativeness [13].

Product innovativeness has two meanings: (1) to provide new offerings, different from previous ones [32,33], and (2) to provide new perceptions of value, utility, and meaning for an old offering among consumers [34]. In the food-service industry, product innovativeness includes adding new items to the menu [35]. Specifically, when faced with rapid changes in consumer taste, improving the taste and diversity of dim sum may help Yumcha restaurants attract more consumers.

Service innovativeness is described as performance-enhancement activities that offer a creative benefit or sufficient appeal. Service innovativeness would intensely influence consumers' and competing companies' behavior [36]. Service innovativeness includes new technology in the services' delivering processes [37]. In a Yumcha restaurant, new technology, such as an app for ordering from the menu or online ordering tools, can be integrated into customers' dining experience and help enhance the delivery process.

Experiential innovativeness is defined as the behaviors to create a customized and personalized experience for customers [38]. First, experiential innovativeness includes a creative or fantasy environment and circumstances in which consumers can engage [39,40]. Providing communal tables encourages a social interactive atmosphere. Traditionally, the Yumcha restaurant is a place for 
customers to chat. Recently, Yumcha restaurants have begun to design the restaurant's atmosphere and add cultural elements to its environment. Second, experiential innovativeness in the hospitality industry focuses on employee-customer interactions [41], a typically people-oriented sector. Yumcha restaurants generally encourage their employees to interact with customers.

Promotion is a firm's marketing method to introduce its products and services to targeted customers [42]. Promotional methods can be creative, such as using digital, mobile, and social media in marketing communications $[43,44]$, creating a new product mix and new ways of giving discounts and gifts [45]. In a Yumcha restaurant, promotional innovation includes various rewards (membership programs), innovative marketing, and advertising strategies. In general restaurants, providing Yumcha products in the morning has become a method of promotion.

\subsection{Impact of Globalization}

The tension between globalization and localization results in rapid sociocultural changes and shocks to local food heritage, and the prospective impact of disruptions may stir restaurants' motivation to respond [46]. More severe external changes and interruptions may greatly motivate restaurants to response, restore stability, and enhance resilience. Harvey employed "time-space compression" to describe recent social changes [2]. In terms of space, the world is experiencing a globalized process [1]. In the food context, the spread of fast-food culture is considered damaging to various traditional food cultures [47]. Homogenization is an expected consequence of globalization, meaning everything becomes the same [48]. Thus, the force of globalization may decrease the diversity of local culture [49]. In terms of time, modern people complain more about the fast pace of life and spend less time in eating, sleeping, and playing [50]. Social acceleration may cause people to reduce their consumption of local food. Thus, we suggest:

Hypothesis 4 (H4). Sociocultural change negatively affects the sustainability of Yumcha culture.

Second, however, social and cultural changes usually occur slowly, which does not destroy enterprises immediately; rather, it gives them more time and space to adapt to the changes. In the process of adapting, the enterprises obtain more abilities to cope with external challenges and become more resilient to strikes. As a result, social and cultural change can be beneficial to restaurants. Therefore, we hypothesize:

Hypothesis 5 (H5). Sociocultural change positively enhances Yumcha restaurants' resilience.

The relationship between dynamic capabilities and restaurant resilience is complex [51]. Contextual factors like rapid sociocultural change may moderate the association. Previous studies have suggested that, in rapidly changing environments, firms with high dynamic capabilities are more resilient [31]. However, when business environments are relatively stable, the benefits created by dynamic capabilities may be overturned by the costs required to develop and maintain such competences [52]. Therefore, we propose:

Hypothesis 6 (H6). Sociocultural change moderates the relationship between dynamic capabilities and Yumcha restaurant resilience.

Based on the previous hypotheses, this research further proposes that the indirect effect of proactive behavior and uncertainty orientation on Yumcha heritage sustainability through Yumcha restaurant resilience should change with different levels of impact. That is to say, the impact should moderate the sequentially mediating effect of Yumcha restaurant resilience in the relationship between proactive behavior, uncertainty orientation, and Yumcha heritage sustainability. Thus: 
Hypothesis 7 (H7). Social-cultural impact moderates the indirect effects of proactive behavior and uncertainty orientation on Yumcha heritage sustainability via Yumcha restaurant resilience.

\section{Methods}

\subsection{Sample, Data Collection, and Research Context}

We conducted a survey based on employees' perceptions. We collected data from Yumcha restaurants in Guangzhou. A pilot survey was conducted with six managers in Yamcha restaurants and two academic experts. The pilot respondents were required to provide comments on the measurement scales' content validity. Based on respondents' comments, we revised the questionnaire until the questionnaire was easy to understand and sufficiently clear.

The survey was conducted in the Haizhu and Yuexiu districts in Guangzhou, Guangdong, China. Yumcha culture originated in the Qing dynasty, between 1862 and 1874, in Guangzhou, Guangdong, China. Early Yumcha restaurants usually had a signboard with the letters "Cha Hua" (茶话). "Cha" (茶) means to drink tea and "Hua" (话) means to talk. This kind of restaurant generally provided several tables and benches for customers to sit, drink tea, and eat snakes (dim sum). Later, much larger Yumcha restaurants opened and Yumcha cultural became popular. In Guangdong, going to a Yumcha restaurant to drink tea and eat dim sum is also called “Tan Cha” (叹茶). “Tan" (叹) has a meaning of enjoyment, and "Tan Cha" is similar to a kind of pleasant recreation activity. In ancient times, Yumcha restaurants provided Yumcha products throughout the day. Yumcha services were its main products. In modern society, some restaurants only provide Yumcha products in the morning. Yumcha services are subsidiary products. Both kinds of restaurants were included as cases in this study.

We used both electronic and hard-copy questionnaires. We used wjx.com to develop the electronic questionnaires. Three university students collected the data between 14:00 and 17:00 every weekend from 16 May to 26 July 2018. Students collected the data mainly in the Haizhu and Yuexiu districts of Guangzhou. Haizhu and Yuexiu are the traditional districts in Guangzhou. Students investigated all the main streets. When they found a Yumcha restaurant, they walked in to introduce our research to the manager of the restaurant and to ask if they and their employees would fill a questionnaire. Students were trained in administering the questionnaire and introducing the questionnaire's background. Questionnaires were administered face to face using the hard-copy edition. If the targeted respondents were working, students asked them if they would complete the electronic questionnaire later. Respondents were offered a chance to win an average 2 RMB bonus in a draw if they completed the electronic survey. To ensure the participants qualified for the study, a screening question was set in the beginning of the survey by asking what kind of food the restaurant in which they work provides.

The number of responses was 262. 14 responses in the electronic version were eliminated because their completion time was less than 2 minutes or their answers were all the same, yielding 248 usable samples. The effective response rate was $94.66 \%$. As the data analysis technique we used was the maximal likelihood method, this sample size was sufficient [53]. By comparing employees' characteristics (i.e., sex, age, and position) of early versus late respondents, nonresponse bias was tested. There were no significant difference.

In the formal survey, the sample characteristics demonstrated that $46 \%$ of the participants were female and $64.7 \%$ were older than 21 years old. Just $36 \%$ of the participants had a high-school degree or above. $45 \%$ of the participants were single and $45 \%$ were born in Guangzhou. Most of the participants $(71.1 \%)$ had lived in Guangzhou for more than 10 years, and $45 \%$ had worked in Yumcha restaurants for more than 5 years.

\subsection{Measures}

In this section, variable definitions are presented. The measures of our study were based on previous studies [54], all using a 7-point Likert scale (1 means strongly disagree, 7 means strongly agree). 
Tables 1 and 2 present all the measurement items. The variables included proxies for sustainability, resilience, impacts, and dynamic capabilities.

Table 1. Exploratory and confirmatory factor analysis for proactive behavior.

\begin{tabular}{|c|c|c|c|c|c|c|c|}
\hline No. & Factor & $\mathbf{M}$ & SD & Skew & Kurt & EFL & CFL \\
\hline & \multicolumn{4}{|c|}{ Product innovativeness (Cronbach's $\alpha: 0.897$, CR: 0.897; AVE: 0.702) } & \multicolumn{3}{|c|}{$18.6 \%{ }^{a}$} \\
\hline At1 & Yumcha restaurants offer new flavors. & 5.41 & 1.417 & -0.654 & -0.024 & 0.750 & 0.794 \\
\hline At2 & Yumcha restaurants offer new combinations of food. & 5.31 & 1.450 & -0.722 & 0.227 & 0.807 & 0.869 \\
\hline At3 & Yumcha restaurants offer innovative presentation of food. & 5.34 & 1.391 & -0.595 & 0.032 & 0.747 & 0.849 \\
\hline At4 & Yumcha restaurants introduce new menu items. & 5.59 & 1.431 & -0.761 & -0.059 & 0.766 & 0.8 \\
\hline & \multicolumn{4}{|c|}{ Service innovativeness (Cronbach's $\alpha: 0.853$, CR: 0.857; AVE: 0.667) } & \multicolumn{3}{|c|}{$14.9 \%{ }^{\mathrm{a}}$} \\
\hline As1 & $\begin{array}{l}\text { Yumcha restaurants' procedure for ordering menu items } \\
\text { is innovative. }\end{array}$ & 5.58 & 1.412 & -0.783 & 0.223 & 0.860 & 0.835 \\
\hline As2 & $\begin{array}{l}\text { Yumcha restaurants integrate innovative technologies in } \\
\text { new processes for offering their services. }\end{array}$ & 5.20 & 1.359 & -0.371 & -0.190 & 0.651 & 0.762 \\
\hline As3 & $\begin{array}{l}\text { Yumcha restaurants' apps or online ordering tools make } \\
\text { Yumcha restaurants make it easier for customers to order } \\
\text { one-of-a-kind menu items compared to its competitors }\end{array}$ & 5.42 & 1.474 & -0.728 & 0.144 & 0.815 & 0.851 \\
\hline & \multicolumn{4}{|c|}{ Experiential innovations (Cronbach's $\alpha: 0.929$, CR: 0.93; AVE: 0.72) } & \multicolumn{3}{|c|}{$20.0 \%{ }^{a}$} \\
\hline Ae1 & $\begin{array}{l}\text { Yumcha restaurants offer unique characteristic features } \\
\text { that set it apart from its competitors. }\end{array}$ & 5.30 & 1.371 & -0.616 & 0.152 & 0.921 & 0.823 \\
\hline Ae2 & Traditional culture is integrated into Yumcha restaurants & 5.65 & 1.375 & -0.792 & 0.144 & 0.779 & 0.812 \\
\hline Ae3 & $\begin{array}{l}\text { The characteristics of Yumcha restaurants provide an } \\
\text { innovative environment that makes them unique. }\end{array}$ & 5.37 & 1.428 & -0.642 & 0.022 & 0.763 & 0.896 \\
\hline Ae4 & $\begin{array}{l}\text { The characteristics of Yumcha restaurants provide an } \\
\text { innovative design that differentiates them from } \\
\text { their competitors. }\end{array}$ & 5.23 & 1.361 & -0.406 & -0.230 & 0.680 & 0.85 \\
\hline Ae5 & $\begin{array}{l}\text { Yumcha restaurants are well-known for innovative } \\
\text { custom events. }\end{array}$ & 5.42 & 1.383 & -0.590 & -0.134 & 0.790 & 0.873 \\
\hline & \multicolumn{4}{|c|}{ Promotional innovativeness (Cronbach's $\alpha: 0.919$, CR: 0.92; AVE: 0.70) } & \multicolumn{3}{|c|}{$21.9 \%$ a } \\
\hline Ap1 & $\begin{array}{l}\text { Yumcha restaurants are always thinking of ways to } \\
\text { expand and offer new benefits to its customers in order } \\
\text { to give them a better experience. }\end{array}$ & 5.12 & 1.397 & -0.397 & -0.326 & 0.713 & 0.837 \\
\hline Ap2 & $\begin{array}{l}\text { The way Yumcha restaurant employees interact with } \\
\text { their customers is innovative. }\end{array}$ & 5.09 & 1.394 & -0.431 & 0.004 & 0.782 & 0.803 \\
\hline Ap3 & $\begin{array}{l}\text { Yumcha restaurants have an innovative rewards } \\
\text { (membership) program. }\end{array}$ & 5.11 & 1.394 & -0.469 & 0.200 & 0.921 & 0.86 \\
\hline Ap4 & $\begin{array}{l}\text { Yumcha restaurants implement new advertising } \\
\text { strategies not currently used by their competitors. }\end{array}$ & 5.25 & 1.368 & -0.376 & -0.262 & 0.766 & 0.843 \\
\hline Ap5 & $\begin{array}{l}\text { Yumcha restaurants adopt novel ways to market } \\
\text { themselves to customers. }\end{array}$ & 5.08 & 1.349 & -0.275 & -0.168 & 0.733 & 0.817 \\
\hline & Cumulative validity & \multicolumn{6}{|c|}{$75.4 \%^{\mathrm{a}}$} \\
\hline
\end{tabular}

Note: Kaiser-Meyer-Olkin measure of sampling adequacy is 0.942, approx. chi-square of Bartlett's test of sphericity is $3636.240(\mathrm{df}=153)$. ${ }^{\text {a }}$ denotes for variance contribution rate. EFL, exploratory factor loadings; $\mathrm{CFL}$, confirmatory factor loadings.

Yumcha heritage sustainability used a 5-item measurement scale. The items were adapted from Jantunen, Tarkiainen, Chari, and Oghazi [52]. The measure of sustainability of Yumcha culture considered the persistence of Yumcha activity and the continuous appreciation of the value involved in the activity. Within the Yumcha heritage context, it measures the continuous appreciation of the value of the Yumcha restaurant industry.

Yumcha restaurant resilience was adapted from Ambulkar et al. [55]. This scale assessed Yumcha restaurants' capability to cope with disruptions and adapt to uncertainties. 
The impact of social-cultural changes has two aspect factors, impact from demand-side changes and impact from market-side changes. Each impact factor of social-cultural changes was measured based on a 3-item scale that was originally from Bode et al. [46]. A revised version was developed for the purposes of this study based on interviews with restaurant managers, academic experts, and members of the Food and Beverage Association of Guangzhou. This variable measured the extent to which the Yumcha restaurant was affected by demand and market changes.

Dynamic capabilities include two aspects, uncertainty orientation and proactive behavior. Measurement items for the uncertainty-orientation dimension incorporated two factors, uncertainty orientation toward demand change, and uncertainty orientation toward market change. It measured the restaurants' alertness to social disruptions. The uncertainty-orientation scale was adapted from Bode et al. [46].

Proactive behavior includes innovations and activities for knowledge and resource acquisition, as well as exploration facilitating resistance to social changes [53]. In the context of Yumcha culture, it includes 4 factors: product innovativeness, service innovativeness, experiential innovativeness, and promotional innovation.

\subsection{Measure Assessment}

A 2-stage procedure was implemented to evaluate measurement scales. In the first stage, exploratory factor analysis was conducted to measure the proactive behavior's structure. Proactive behavior is a second-order construct. Exploratory factor analysis was to test whether items formed the expected proactive behavior factors. Factor analysis used the oblique-rotation method. Items with a low factor loading of 0.5 were abandoned. The reserved items' factor loadings were all greater than 0.6 on their corresponding factors. We considered all factor loadings as significant [56]. Next, confirmatory factor analysis was performed to assess the convergence. Four factors (product innovativeness, service innovativeness, experiential innovativeness, promotional innovation) were included in the proactive-behavior construct.

The second stage was assessing the convergent and discriminant validity of the 5 key constructs with confirmatory factor analysis (Table 2). We used software package Mplus 7.0 [57] and employed the maximum-likelihood (ML) estimator, which is the default estimator in Mplus recommended by Henseler, Ringle, and Sarstedt [58]. All of the factor loadings were significant and higher than 0.6. Cronbach's $\alpha$ and composite reliability (CR) for each measure was computed to assess the reliability and convergent validity of the scales. Factor loadings of all items were greater than 0.7 . It showed that reliability and convergent validity was indicated [59]. The average variance extracted (AVE) was further computed to assess validity. AVE was higher than 0.5 [57] for all measures.

To further evaluate the discriminant validity of the 5 constructs, we followed strict procedures adopted from advanced research [60]. We compared the 5-factor key structure model with alternative plausible models. Table 3 shows the results. Based on the results, the proposed 5 -factor model provided a better fit to the data $\left(\chi^{2}(125)=193.491, p<0.01\right.$; the comparative fit index $(C F I)=0.967$; the Tucker-Lewis index (TLI) $=0.960$; Root Mean Square Error of Approximation (RMSEA) $=0.047$; standard root mean square residual $($ SRMR $)=0.037)$ [61]. Thus, the discriminant validity of the five-factor key structure was confirmed. 
Table 2. Confirmatory factor analysis for resilience and sustainability.

\begin{tabular}{|c|c|c|c|c|c|c|}
\hline & Factor & Mean & SD & Skewness & Kurtosis & $\begin{array}{l}\text { C Factor } \\
\text { Loading }\end{array}$ \\
\hline \multicolumn{7}{|c|}{ Proactive behavior (Cronbach's $\alpha: 0.880$, composite reliability (CR): 0.89 ; average variance extracted (AVE): 0.67 ) } \\
\hline P1 & Product innovativeness & 5.41 & 1.243 & -0.789 & 0.641 & 0.780 \\
\hline P2 & Service innovativeness & 5.40 & 1.245 & -0.644 & 0.449 & 0.755 \\
\hline P3 & Experiential innovativeness & 5.39 & 1.221 & -0.619 & 0.336 & 0.883 \\
\hline $\mathrm{P} 4$ & Promotional innovation & 5.13 & 1.201 & -0.341 & 0.281 & 0.85 \\
\hline \multicolumn{7}{|c|}{ Uncertainty orientation of demand change (Cronbach's $\alpha: 0.880$, CR: 0.88; AVE: 0.65) } \\
\hline $\mathrm{U} 1$ & $\begin{array}{l}\text { Various social changes have highlighted the fragility of } \\
\text { Yumcha restaurants and demonstrated improvements to } \\
\text { Yumcha restaurants. }\end{array}$ & 4.96 & 1.286 & -0.151 & -0.057 & 0.719 \\
\hline $\mathrm{U} 2$ & $\begin{array}{l}\text { Yumcha restaurants recognize the impact of social change } \\
\text { at any time. }\end{array}$ & 5.04 & 1.251 & -0.106 & -0.201 & 0.819 \\
\hline $\mathrm{U} 3$ & $\begin{array}{l}\text { Yumcha restaurants have done a lot to better cope with } \\
\text { social changes. }\end{array}$ & 5.15 & 1.243 & -0.095 & -0.299 & 0.827 \\
\hline $\mathrm{U} 4$ & The impact on Yumcha restaurants is constantly reviewed. & 5.17 & 1.272 & -0.306 & -0.168 & 0.859 \\
\hline \multicolumn{7}{|c|}{ Social-cultural changes (Cronbach's $\alpha$ : 0.859, CR: 0.86; AVE: 0.62) } \\
\hline $\operatorname{Im} 1$ & Social change affects the Yumcha restaurant industry & 4.82 & 1.526 & -0.490 & -0.047 & 0.600 \\
\hline $\operatorname{Im} 2$ & $\begin{array}{l}\text { Customer tastes change increasingly faster, affecting the } \\
\text { morning-tea industry. }\end{array}$ & 4.64 & 1.589 & -0.409 & -0.116 & 0.842 \\
\hline $\operatorname{Im} 3$ & $\begin{array}{l}\text { The way of life is getting increasingly faster in the Yumcha } \\
\text { restaurant industry }\end{array}$ & 4.54 & 1.545 & -0.356 & -0.123 & 0.881 \\
\hline $\operatorname{Im} 4$ & $\begin{array}{l}\text { All kinds of catering enterprises continue to increase, } \\
\text { affecting the morning-tea industry. }\end{array}$ & 4.50 & 1.574 & -0.448 & -0.059 & 0.803 \\
\hline \multicolumn{7}{|c|}{ Yumcha heritage resilience (Cronbach's $\alpha: 0.898$, CR: 0.90; AVE: 0.69) } \\
\hline R1 & Yumcha culture can adapt to the impact of various shocks. & 4.84 & 1.285 & -0.077 & -0.110 & 0.832 \\
\hline R2 & $\begin{array}{l}\text { Yumcha restaurants can respond quickly to the impact of } \\
\text { various shocks. }\end{array}$ & 4.73 & 1.298 & 0.002 & -0.087 & 0.854 \\
\hline R3 & $\begin{array}{l}\text { Yumcha restaurants have enough capacity to adapt to all } \\
\text { kinds of impact. }\end{array}$ & 4.80 & 1.388 & -0.339 & 0.193 & 0.818 \\
\hline R4 & $\begin{array}{l}\text { Yumcha restaurants can quickly adjust business operations } \\
\text { to cope with all kinds of impact. }\end{array}$ & 4.83 & 1.304 & -0.131 & 0.091 & 0.814 \\
\hline \multicolumn{7}{|c|}{ Sustainability of Yumcha culture (Cronbach's $\alpha: 0.901$, CR: 0.91; AVE: 0.76) } \\
\hline Fu1 & I am full of confidence in the Yumcha restaurant industry & 5.38 & 1.386 & -0.629 & -0.007 & 0.915 \\
\hline Fu2 & I think the Yumcha restaurant industry has a good future & 5.36 & 1.373 & -0.601 & 0.112 & 0.903 \\
\hline Fu3 & $I^{\prime} d$ be happy to work in the Yumcha restaurant industry & 5.33 & 1.499 & -0.644 & -0.194 & 0.795 \\
\hline
\end{tabular}

Table 3. Results of the confirmatory factor analysis for the measurement scales.

\begin{tabular}{|c|c|c|c|c|c|c|c|}
\hline & & $x^{2}$ & $D f$ & RMSEA & SRMR & CFI & TLI \\
\hline 1 & Five-factor model & 193.491 & 125 & 0.047 & 0.037 & 0.967 & 0.960 \\
\hline 2 & $\begin{array}{l}\text { Four-factor model: dynamic capability and uncertainty } \\
\text { orientation were combined into one factor. }\end{array}$ & 301.339 & 129 & 0.073 & 0.051 & 0.918 & 0.903 \\
\hline 3 & $\begin{array}{l}\text { Three-factor model: Dynamic capability, uncertainty } \\
\text { orientation, and impact were combined into one factor }\end{array}$ & 527.936 & 132 & 0.110 & 0.091 & 0.811 & 0.781 \\
\hline 4 & $\begin{array}{l}\text { Two-factor model: dynamic capability, uncertainty } \\
\text { orientation, impact, and business resilience were } \\
\text { combined into one factor }\end{array}$ & 625.729 & 134 & 0.122 & 0.094 & 0.766 & 0.732 \\
\hline 5 & All variables were combined into one factor & 757.691 & 135 & 0.136 & 0.102 & 0.703 & 0.664 \\
\hline
\end{tabular}




\section{Results}

\subsection{Descriptive Statistics}

Table 4 reports the correlation of all the variables in this study. Results suggest that the sustainability of Yumcha culture is positively correlated with proactive behavior $(\mathrm{r}=0.793, p<0.01)$, uncertainty orientation $(\mathrm{r}=0.707, p<0.01)$, social-cultural changes $(\mathrm{r}=0.24, p<0.01)$, and Yumcha restaurant resilience $(\mathrm{r}=0.645, p<0.01)$. Moreover, Yumcha restaurant resilience is positively correlated with proactive behavior $(\mathrm{r}=0.712, p<0.01)$, uncertainty orientation $(\mathrm{r}=0.746, p<0.01)$, and social-cultural changes $(\mathrm{r}=0.599, p<0.01)$. In addition, social-cultural changes are positively correlated with proactive behavior $(\mathrm{r}=0.397, p<0.01)$ and uncertainty orientation $(\mathrm{r}=0.502, p<0.01)$.

Table 4. Correlation matrix.

\begin{tabular}{llcccc}
\hline & & $\mathbf{1}$ & $\mathbf{2}$ & $\mathbf{3}$ & $\mathbf{4}$ \\
\hline 1 & Proactive behavior & 1 & & & \\
2 & Uncertainty orientation & 0.766 & 1 & & \\
3 & Social-culture changes & 0.397 & 0.502 & 1 & \\
4 & Yumcha restaurant resilience & 0.712 & 0.746 & 0.599 & 1 \\
5 & Yumcha culture sustainability & 0.793 & 0.707 & 0.24 & 0.645 \\
\hline
\end{tabular}

\subsection{Hypothesis Test}

Structural equation modeling (SEM) was chosen as the analyzing method to test the hypothesized model. SEM helps provide a comprehensive examination of all paths and the overall fit of data in the model [62]. To estimate the single-item measures, the measurement path was set as one and assumed no error [63]. Following previous studies' approach [64], the error and measurement path of the interaction was set. Two methods were used to measure the hypothesized model (with moderate effect), the product-indicator approach [65] and latent moderated structural equations (LMS) approach. The results of the product-indicator approach are shown in M1 of Table 5. The results of LMS are shown in M2 of Table 5.

Table 5. Comparison of structural equation models.

\begin{tabular}{|c|c|c|c|c|c|c|c|c|}
\hline & M1 & M2 & M3 & M4 & M5 & M6 & M7 & M8 \\
\hline $\mathrm{R}->\mathrm{S}$ & $0.212 * *$ & $0.215^{*}$ & $0.706^{* * *}$ & $0.208^{*}$ & $0.294^{* * *}$ & $0.235^{* *}$ & $0.690 * *$ & $0.198^{* *}$ \\
\hline behavior->R & $0.374^{* * *}$ & $0.361^{* * *}$ & $0.396^{* * *}$ & $0.331^{* *}$ & $0.358^{* * *}$ & $0.413^{* * *}$ & $0.422^{* * *}$ & \\
\hline Orientation $->R$ & $0.363^{* * *}$ & $0.359 * * *$ & $0.473^{* * *}$ & $0.344^{* *}$ & $0.378^{* * *}$ & $0.420 * * *$ & $0.377^{* * *}$ & \\
\hline Chang->R & $0.234^{* * *}$ & $0.248^{* * *}$ & & $0.295^{* * *}$ & $0.235^{* * *}$ & $0.181^{* * *}$ & $0.190 * * *$ & \\
\hline $\begin{array}{c}\text { Behavior * } \\
\text { Change- }>\mathrm{R}\end{array}$ & $0.163^{* * *}$ & 0.110 * & & & $0.162^{* * *}$ & $0.076^{* * *}$ & $0.156^{* * *}$ & \\
\hline Behavior->S & $0.544^{* * *}$ & $0.532 * * *$ & & $0.544^{* * *}$ & $0.674^{* * *}$ & $0.729 * * *$ & & $0.557^{* * *}$ \\
\hline Orientation- $>S$ & $0.244^{* * *}$ & $0.247^{* *}$ & & $0.249^{* *}$ & & $0.347^{* * *}$ & & $0.253^{* * *}$ \\
\hline Change->S & $-0.224^{* * *}$ & $-0.219 * * *$ & & $-0.226^{* * *}$ & $-0.201^{* * *}$ & $-0.212 * * *$ & & $-0.231^{* * *}$ \\
\hline $\begin{array}{l}\text { Behavior * } \\
\text { Change- }>S\end{array}$ & & & & & & 0.014 & & 0.025 \\
\hline$x^{2}$ & 397.521 & & 287.555 & 325.586 & 404.171 & 397.298 & 493.051 & 397.298 \\
\hline Df & 175 & & 86 & 157 & 176 & 174 & 178 & 174 \\
\hline$\Delta \chi^{2}(\Delta D f)$ & & & $110(89)$ & $-72(18)$ & $6(1)$ & $-0.3(1)$ & $104(3)$ & $-0.23(1)$ \\
\hline RMSEA & 0.072 & & 0.097 & 0.066 & 0.072 & 0.072 & 0.084 & 0.072 \\
\hline SRMR & 0.045 & & 0.076 & 0.049 & 0.047 & 0.045 & & 0.045 \\
\hline CFI & 0.943 & & 0.929 & 0.949 & 0.942 & 0.943 & 0.920 & 0.943 \\
\hline TFI & 0.932 & & 0.913 & 0.939 & 0.931 & 0.931 & 0.905 & 0.931 \\
\hline AIC & $15,065.95$ & $12,165.86$ & 9912.32 & $12,172.44$ & $15,070.60$ & $15,067.72$ & $15,155.48$ & $15,067.72$ \\
\hline ABIC & $15,085.18$ & $12,188.53$ & 9929.15 & $12,194.42$ & $15,089.48$ & $15,087.30$ & $15,173.68$ & $15,087.30$ \\
\hline
\end{tabular}

Note: R: Yumcha restaurant resilience; S: Yumcha culture sustainability; Behavior: proactive behavior; Orientation: uncertainty orientation; Change: social-cultural changes; RMSEA: Root Mean Square Error of Approximation; SRMR: Standardized Root Mean Square Residual; AIC: Akaike Information Criteria; ABIC: Sample-Size Adjusted Bayesian Information Criteria. $* * *, * * *$ denote significant results at the $0.10,0.05$, and 0.01 confidence levels, respectively. 


\subsection{Model Comparison}

Five alternative plausible models were constructed to compare with the hypothesized model measured by the product-indicator approach (M1) utilizing the test of $\chi^{2}$ statistics [66]. Two of the alternative models were without moderate effect (M3 and M4). M5 is an alternative partial mediation model, and estimated the hypothesized model without links from uncertainty orientation to the sustainability of Yumcha culture. M6, an alternative full model, estimated the hypothesized model with the link from proactive behavior $\times$ social-cultural changes to the sustainability of Yumcha culture. M7, an alternative full-mediation model, estimated the hypothesized model without links from proactive behavior, uncertainty orientation, and social-cultural changes to the sustainability of Yumcha culture. M8, a model without mediation, estimated the hypothesized model without links from proactive behavior, uncertainty orientation, and social-cultural changes to Yumcha restaurant resilience.

The results of the changes in $\chi^{2}$ tests are shown in Table 5. The result of M1 indicates that the hypothesized model provides the best fit in the data compare to models M5-M8 ( $\chi^{2}(175)=397.521$; CFI = 0.943; TLI = 0.932; Root Mean Square Error of Approximation (RMSEA) = 0.072; Standardized Root Mean Square Residual (SRMR) = 0.045). The goodness of fit of the M4 result, which is an alternative model without moderate effect, is slightly higher than the hypothesized model. However, we argue that our hypothesized model is the best for two reasons. First, the moderate effect in M1 is significant. Second, the Akaike Information Criteria (AIC) and Sample-Size Adjusted Bayesian Information Criteria (ABIC) of M2, which is the hypothesized model estimated by LMS, are lower than M4. AIC and ABIC are the goodness of fit indices used to compare the results between the LMS approach and the product-indicator approach.

\subsection{Hypothesis Testing}

Results of structural equation modeling analysis are presented in Figure 2. In support of Hypothesis 1, Yumcha restaurant resilience is confirmed to be positively related to the sustainability of Yumcha culture $(\beta=0.212, p<0.05)$. Proactive behavior $(\beta=0.374, p<0.01)$ and uncertainty orientation $(\beta=0.363, p<0.01)$ are positively related to Yumcha restaurant resilience, thus supporting Hypotheses $2 \mathrm{a}$ and 3a. Proactive behavior $(\beta=0.544, p<0.01)$ and uncertainty orientation $(\beta=0.244, p<0.01)$ are positively related to the sustainability of Yumcha culture, thus supporting Hypotheses $2 b$ and $3 b$. Sociocultural change $(\beta=0.234, p<0.05)$ is negatively related to the sustainability of Yumcha culture, thus supporting Hypothesis 4 . Sociocultural change $(\beta=0.234, p<0.05)$ and proactive behavior $\times$ sociocultural change $(\beta=0.163, p<0.05)$ are positively associated to Yumcha restaurant resilience, thus supporting Hypotheses 5 and 6.

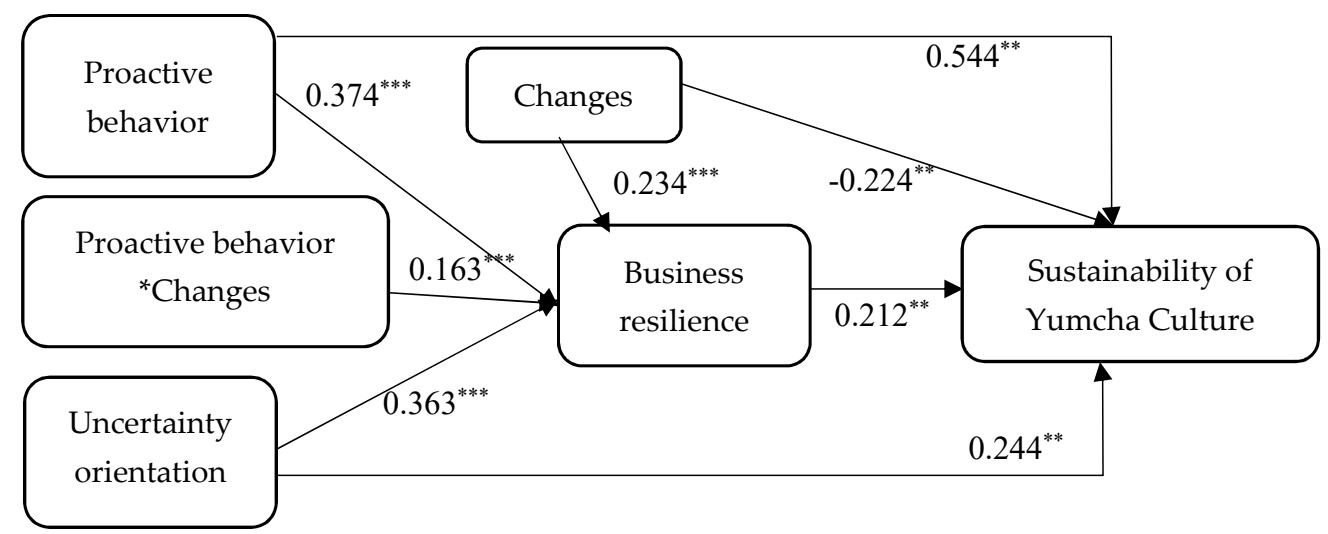

Figure 2. Results of path analysis. Note: $\mathrm{N}=248 ;{ }^{* * *} p<0.01 ;{ }^{* *} p<0.05$. It is a simplified version of the proposed model. Error terms, indicators, exogenous factor variances, and correlations among exogenous factors are not shown. 
Interaction effects are plotted in Figure 3 using Aiken and West's procedure [67]. Figure 3 shows that the association between proactive behavior and Yumcha restaurant resilience is stronger when social-cultural changes are high $(\beta=0.218, p<0.01)$ rather than low $(\beta=0.164, p<0.05)$. Thus, Hypothesis 7 receives further support.

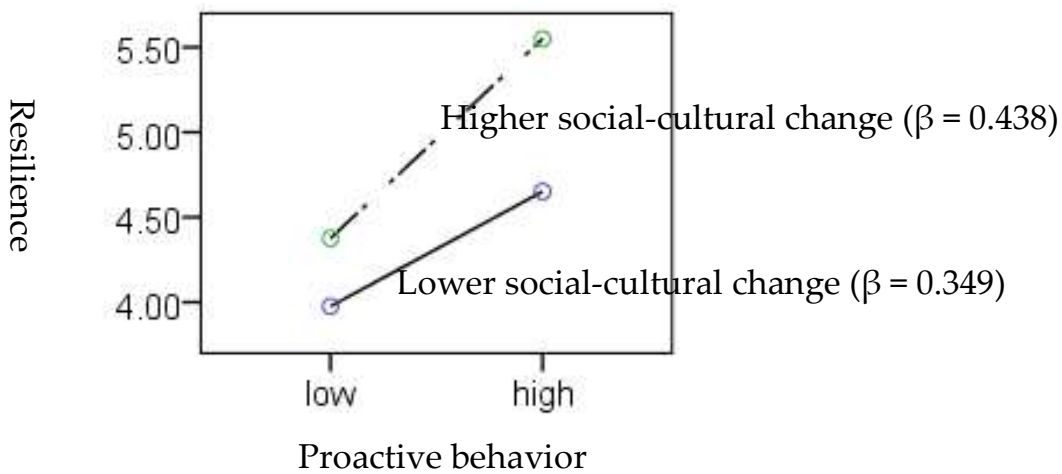

Figure 3. The moderating effect of social-cultural changes on the relationship between proactive behavior and resilience.

Hypothesis 5 proposed that Yumcha restaurant resilience mediates the relationships among proactive behavior, uncertainty orientation, impacts, proactive behavior $\times$ impact, and the sustainability of Yumcha culture. The model with a direct path from proactive behavior, uncertainty orientation, impact, proactive behavior $\times$ impact, to the sustainability of Yumcha culture did not show a significantly better fit than the hypothesized model. The mediation effect in Hypothesis 5 finds support.

Table 6. Summary of conditional indirect effects.

\begin{tabular}{cccccc}
\hline \multirow{2}{*}{ Path } & Class & Coefficient & Posterior S.D. & \multicolumn{2}{c}{ 95\% Confidence Intervals } \\
\cline { 5 - 6 } & & & & Lower & Higher \\
\hline \multirow{2}{*}{ behavior- $>\mathrm{R}$} & Higher social-cultural changes & 1.019 & 0.092 & 0.837 & 1.194 \\
& Lower social-cultural changes & 0.649 & 0.087 & 0.477 & 0.817 \\
& Difference in direct effect & 0.371 & 0.123 & 0.123 & 0.611 \\
\hline \multirow{2}{*}{ indirect effect } & Higher social-cultural changes & 0.247 & 0.078 & 0.103 & 0.412 \\
& Lower social-cultural changes & 0.155 & 0.052 & 0.063 & 0.268 \\
& Difference in indirect effect & 0.086 & 0.041 & 0.022 & 0.185 \\
\hline
\end{tabular}

Notes: sample size of the higher social-cultural-change category is 91; sample size of the lower social-culturalchange category is 154; all the coefficients are unstandardized. The conditional indirect-effect tests were estimated using Bayes estimator with four Markov chain Monte Carlo (MCMC) chains. Fixed number of iterations for each MCMC chain was 1000.

Moderated path analysis was evaluated in Mplus 7.0 using the Bayes estimator with four Markov chain Monte Carlo (MCMC) chains to test Hypothesis 7 [68]. As displayed in Table 6, the indirect effect of proactive behavior on the sustainability of Yumcha culture via Yumcha restaurant resilience varies significantly across different levels of social-cultural changes $(\Delta \beta=0.086, p<0.05)$. Hence, Hypothesis 7 receives support. Specifically, the indirect effect of proactive behavior on the sustainability of Yumcha culture was stronger when the level of impact is high $(\beta=0.247, p<0.01)$ rather than low $(\beta=0.155$, $p<0.05)$. This provides further support for Hypothesis 7 . Therefore, all the hypotheses in our study receive full support. 


\section{Conclusions and Discussion}

\subsection{Conclusions}

This study shed light on the sustainability of food heritage under sociocultural changes from a restaurant perspective. Guangzhou quickly changed from a small city to a large metropolis within 40 years after China's opening policy. Choosing Guangzhou's Yumcha heritage as the case, we proposed that Yumcha restaurant resilience enhances Yumcha heritage sustainability. Dynamic capabilities were proposed having positive influence on the sustainability of Yumcha heritage via Yumcha restaurant resilience in the modern world. These hypotheses draw on the resilience perspective. The findings make contributions in three aspects: (1) Yumcha restaurant resilience positively affects Yumcha heritage sustainability, (2) business resilience mediates the effects between restaurants' dynamic capability and food-heritage sustainability, and (3) the effects from dynamic capabilities to heritage sustainability are modified by social-cultural impact.

This research makes four theoretical contributions. First, this study expands the culture-heritage literature by focusing on the effect of business resilience of restaurants in heritage sustainability, where the restaurants' dynamic capability is prevalent and may generate important influence, but its effects have not been fully investigated [14]. This research suggests that business resilience could contribute to heritage sustainability. Such findings provide evidence for the positive impact of business resilience on building food-heritage sustainability. Previous research tends to regard the commodification of heritage as damage to the authenticity of heritage [16,69]. This study proves that business with resilient capabilities can enhance the surviving ability of cultural heritage. These findings are not only effective in the conservation of food culture, but also in other types of cultural heritage. For instance, Dai and $\mathrm{Xu}$ found that business brought by tourism development would benefit the protection of tangible-architecture heritage in ancient towns in China [70].

Second, this research made contributions to current business-resilience research. Existing research mainly evaluates business resilience with business performance [52]. This study enhances the understanding of the power of business resilience by focusing on its contributions in preserving heritage. Existing business-resilience research on dynamic capabilities is also constrained. Our study extends the scope to examine specific dynamic capability in the restaurant industry. Five innovations were examined to measure the proactive behavior in building business dynamic capabilities. The advantages caused by enterprise development should not only be measured by the economic gains, but also by the benefits to cultural preservation.

Third, this study unraveled the mediating mechanisms between restaurants' dynamic capability and food-heritage sustainability. Although research about business dynamic capabilities is a recent hot topic [18,52], the process through which capability may influence business resilience and the mediating mechanisms of business resilience have not yet been sufficiently studied, and this paper provide a vivid context to explain the mechanisms [18]. This paper highlights the mediating effects of business resilience in restaurant innovation in helping conserve sustainable food heritage. Business resilience as a mediator links the dynamic capability of enterprises with the sustainability of culture. Various innovations in cultural commodification are crucial means to obtain cultural sustainability.

Fourth, our study further tests the moderating effect of impact. This result supports that effects from dynamic capabilities on heritage sustainability may be modified by impact, consistent with previous research [18]. We therefore expand previous research and argue that impacts provide challenges for business resilience; however, on the other hand, impacts may augment the positive effects from dynamic capability to business resilience. The study argues that identification of social-cultural changes' moderating effect can alleviate their negative effects [18].

\subsection{Practical Implications}

There are several implications for sustainable food-culture conservation according to the research results and conclusions. 
This research suggests that business resilience is crucial for heritage sustainability. This is especially true for restaurants in preserving food heritage, which has been categorized as a tangible heritage. Traditional food-heritage articles appeal for adjustments in human behavior to adopt traditional food. For instance, many studies advocate that people change their dining preferences to choose slower food [71,72]. Our results show that these slow-food activists just try to "return to a primitive, preindustrial economy" [72] (p. 168), which is unrealistic in modern society. However, our study indicates that to preserve food heritage, resilient capacities of restaurants are key factors. If restaurants implement more innovation, they tend to have high levels of business resilience, which helps them survive when facing social-cultural changes. Thus, in the case of European slow food, it is more resilient to make innovations to improve local culinary heritage rather than stick to the authenticity and resist any change. Helping food-heritage restaurants be more resilient may contribute to food-heritage sustainability. For restaurants managers, it is crucial to change minds to make changes and innovations and become more resilient. For instance, many Yumcha restaurants use traditional cooking techniques to create new cuisines to meet new market demands. Some of them also adopt automatic ordering systems to reduce costs and meet younger people's consuming preferences. Government officials should take measures for the spillover effect of food-heritage restaurants when developing food-heritage sustainability strategies. The government should encourage restaurants to innovate with policy and financial support, for instance, by providing innovation funds or low-interest loans for restaurants.

Shocks can push enterprises to innovate. Usually, innovation follows awareness of its necessity. However, this study shows that sometimes internal innovation consciousness does not emerge naturally; external shocks can make enterprises generate the demand for innovation. Research results illustrate that, when external shocks are at a low level, the benefits generated from innovation are fewer. A stronger shock can create increasing innovation desire and more profits. For managers, it is important to be sensitive to external shocks and seize every chance to make innovations.

It is common to emphasize cultural authenticity in the sustainable conservation of cultural heritage. However, in our research, restaurant innovation has a strong positive influence on food-heritage sustainability. This means the change and innovation of cuisines can also contribute to the sustainability of food heritage. In China, people usually do not evaluate food by the authenticity of its taste. People can accept innovative tastes if the new tastes produce a high-quality experience. Therefore, we argue that it is also important to change the food culture according to social and cultural change to conserve the intangible food heritage.

\subsection{Limitations and Future Research}

The first limitation is considering other types of cultural heritage less. Examining different kinds of food heritages, such as Western food heritage, would be interesting for future research. The second limitation is that the data were derived just from a single questionnaire, so future studies could do a cross-sectional survey or a longitudinal study to assess the sustainability of food heritage over time. In terms of research method, it would also be beneficial to use qualitative methods to deeply explore business firms' capabilities and their influence on firm resilience and cultural sustainability. Finally, examining the conclusions from this research in a broader range of social and cultural contexts would show comprehensive mechanisms of how specific business capabilities influence cultural sustainability in different social-cultural environments.

Author Contributions: Conceptualization, S.D., Q.C. and H.X.; Methodology, S.D.; Software, S.D.; Validation, S.D. and H.X.; Formal Analysis, S.D.; Investigation, S.D.; Resources, H.X.; Data Curation, S.D.; Writing-Original Draft Preparation, S.D., Q.C.; Writing-Review and Editing, S.D., Q.C.; Visualization, S.D.; Supervision, H.X.; Project Administration, Q.C., H.X.; Funding Acquisition, S.D.

Funding: This research was funded by National Natural Science Foundation of China, grant number [41601611].

Conflicts of Interest: The authors declare no conflict of interest. 


\section{References}

1. Robertson, R. Globalization: Social Theory and Global Culture; Sage: London, UK, 1992.

2. Harvey, D. The Condition of Postmodernity; Blackwell: Oxford, UK, 1990.

3. Tan, S.K.; Tan, S.H.; Kok, Y.S.; Choon, S.W. Sense of place and sustainability of intangible cultural heritage-The case of George Town and Melaka. Tour. Manag. 2018, 67, 376-387. [CrossRef]

4. Long, L.M. Culinary tourism: A folkloristic perspective on eating and otherness. South. Folklore 1998, 55, 181.

5. Henderson, J.C. Food as a tourism resource: A view from Singapore. Tour. Recreat. Res. 2004, 29, 69-74. [CrossRef]

6. Jiménez-Beltrán, F.J.; López-Guzmán, T.; González Santa Cruz, F. Analysis of the relationship between tourism and food culture. Sustainability 2016, 8, 418. [CrossRef]

7. Broadway, M.J. 'Putting place on a plate' along the West Cork Food Trail. Tour. Geogr. 2017, 19, 467-482. [CrossRef]

8. Dimitrovski, D.; Vallbona, M.C. Urban food markets in the context of a tourist attraction-La Boqueria market in Barcelona, Spain. Tour. Geogr. 2018, 20, 397-417. [CrossRef]

9. Tam, S.M. Heunggongyan forever: Immigrant life and Hong Kong style Yumcha in Australia. In The Globalization of Chinese Food; Wu, D.Y.H., Cheung, S.C.H., Eds.; University of Hawaii Press: Honolulu, HI, USA, 2002; pp. 131-151.

10. Chen, L. Tea and Dim Sum: Cantonese Style Morning Tea; Guangdong Education Press: Guangzhou, China, 2009.

11. Song, S. The impacts of Guangdong Zaocha culture on table manners and modern lifestyles. Mod. Commun. 2018, 6, 103-105.

12. Larsson, M.; Milestad, R.; Hahn, T.; Von Oelreich, J. The resilience of a sustainability entrepreneur in the Swedish food system. Sustainability 2016, 8, 550. [CrossRef]

13. Kim, E.; Tang, L.R.; Bosselman, R. Measuring customer perceptions of restaurant innovativeness: Developing and validating a scale. Int. J. Hosp. Manag. 2018, 74, 85-98. [CrossRef]

14. Zeng, G.; Zhao, Y.; Sun, S. Sustainable development mechanism of food culture's translocal production based on authenticity. Sustainability 2014, 6, 7030-7047. [CrossRef]

15. Prideaux, B. Commodifying Heritage: Loss of Authenticity and Meaning or an Appropriate Response to Difficult Circumstances? Int. J. Tour. Sci. 2003, 3, 1-15. [CrossRef]

16. Bao, J.; Lin, M. Study on control of tourism commercialization in historic town and village. Acta Geogr. Sin. 2014, 69, 268-277.

17. Su, J. Understanding the changing Intangible Cultural Heritage in tourism commodification: The music players' perspective from Lijiang, China. J. Tour. Cult. Chang. 2018. [CrossRef]

18. Parker, H.; Ameen, K. The role of resilience capabilities in shaping how firms respond to disruptions. J. Bus. Res. 2017, 88, 535-541. [CrossRef]

19. Teece, D.J.; Pisano, G.; Shuen, A. Dynamic capabilities and strategic management. Strateg. Manag. J. 1997, 18, 509-533. [CrossRef]

20. WCED. Our Common Future; Oxford University Press: Oxford, UK, 1987; p. 43.

21. Throsby, D. Sustainability and culture some theoretical issues. Int. J. Cult. Policy 1997, 4, 7-19. [CrossRef]

22. Coben, L.S. Sustainability and Cultural Heritage. In Encyclopedia of Global Archaeology; Smith, C., Ed.; Springer Reference: New York, NY, USA, 2014; pp. 7155-7157.

23. Daskon, C.D. Cultural resilience-the roles of cultural traditions in sustaining rural livelihoods: A case study from rural Kandyan villages in Central Sri Lanka. Sustainability 2010, 2, 1080-1100. [CrossRef]

24. Guo, Y.R.; Zhang, J. Research progress and themes of geography on community resilience. Prog. Geogr. 2015, 34, 100-109.

25. Lew, A.A. Scale, change and resilience in community tourism planning. Tour. Geogr. 2014, 16, 14-22. [CrossRef]

26. Roundy, P.T.; Brockman, B.K.; Bradshaw, M. The resilience of entrepreneurial ecosystems. J. Bus. Ventur. Insight 2017, 8, 99-104. [CrossRef]

27. Van Der Vegt, G.S.; Essens, P.; Wahlström, M.; George, G. Managing risk and resilience. Acad. Manag. J. 2015, 58, 971-980. [CrossRef] 
28. Helfat, C.E.; Winter, S.G. Untangling dynamic and operational capabilities: Strategy for the (N)ever-changing world. Strateg. Manag. J. 2011, 32, 1243-1250. [CrossRef]

29. Winter, S.G. Understanding dynamic capabilities. Strateg. Manag. J. 2003, 24, 991-995. [CrossRef]

30. Jantunen, A.; Puumalainen, K.; Saarenketo, S.; Kyläheiko, K. Entrepreneurial orientation, dynamic capabilities and international performance. J. Int. Entrep. 2005, 3, 223-243. [CrossRef]

31. Teece, D.J. Explicating dynamic capabilities: The nature and microfoundations of (sustainable) enterprise performance. Strateg. Manag. J. 2007, 28, 1319-1350. [CrossRef]

32. Ali, A.; Krapfel, R.; LaBahn, D. Product innovativeness and entry strategy: Impact on cycle time and break-even time. J. Prod. Innov. Manag. 1995, 12, 54-69. [CrossRef]

33. Garcia, R.; Calantone, R. A critical look at technological innovation typology and innovativeness terminology: A literature review. J. Prod. Innov. Manag. 2002, 19, 110-132. [CrossRef]

34. Rubera, G.; Ordanini, A.; Griffith, D.A. Incorporating cultural values for understanding the influence of perceived product creativity on intention to buy: An examination in Italy and the US. J. Int. Bus. Stud. 2011, 42, 459-476. [CrossRef]

35. Feltenstein, A. An intertemporal general equilibrium analysis of financial crowding out: A policy model and an application to Australia. J. Public. Econ. 1986, 31, 79-104. [CrossRef]

36. Berry, L.L.; Shankar, V.; Parish, J.T.; Cadwallader, S.; Dotzel, T. Creating new markets through service innovation. MIT Sloan Manag. Rev. 2006, 47, 56-63.

37. Reid, R.D.; Sandler, M. The use of technology to improve service quality: A look at the extent of service improvements to be gained through investments in technology and expanded facilities and programs. Cornell Hosp. Q. 1992, 33, 68-73.

38. Prahalad, C.K.; Ramaswamy, V. The new frontier of experience innovation. MIT Sloan Manag. Rev. 2003, $44,12-18$.

39. Sashi, C.M. Customer engagement, buyer-seller relationships, and social media. Manag. Decis. 2012, 50, 253-272. [CrossRef]

40. Sipe, L.J. How do senior managers influence experience innovation? Insights from a hospitality marketplace. Int. J. Hosp. Manag. 2016, 54, 75-83. [CrossRef]

41. Jernsand, E.M.; Kraff, H.; Mossberg, L. Tourism experience innovation through design. Scand. J. Hosp. Tour. 2015, 15, 98-119. [CrossRef]

42. Grewal, D.; Ailawadi, K.L.; Gauri, D.; Hall, K.; Kopalle, P.; Robertson, J.R. Innovations in retail pricing and promotions. J. Retail. 2011, 87, 43-52. [CrossRef]

43. Doherty, N.F.; Ellis-Chadwick, F. Internet retailing: The past, the present and the future. Int. J. Retail Distrib. Manag. 2010, 38, 943-965. [CrossRef]

44. Shankar, V.; Inman, J.J.; Mantrala, M.; Kelley, E.; Rizley, R. Innovations in shopper marketing: Current insights and future research issues. J. Retail. 2011, 87, 29-42. [CrossRef]

45. Lin, C.Y.; Marshall, D.; Dawson, J. How does perceived convenience retailer innovativeness create value for the customer? Int. J. Bus. Econ. 2013, 12, 171-179.

46. Bode, C.; Wagner, S.M.; Petersen, K.J.; Ellram, L.M. Understanding responses to supply chain disruptions: Insights from information processing and resource dependence perspectives. Acad. Manag. J. 2011, 54, 833-856. [CrossRef]

47. Gaytán, M.S. Globalizing resistance: Slow Food and new local imaginaries. Food Cult. Soc. 2004, 7, 97-116. [CrossRef]

48. McManus, R. Homogenization. In Globalization: The Key Concepts; Mooney, A., Evans, B., Eds.; Routledge: London, UK, 2007; pp. 123-124.

49. Ritzer, G.; Ryan, M. The globalization of nothing. Soc. Thought Res. 2002, 25, 51-81. [CrossRef]

50. Rosa, H. Social Acceleration: A New Theory of Modernity; Columbia University Press: New York, NY, USA, 2013.

51. Fainshmidt, S.; Pezeshkan, A.; Lance Frazier, M.; Nair, A.; Markowski, E. Dynamic capabilities and organizational performance: A meta-analytic evaluation and extension. J. Manag. Stud. 2016, 53, 1348-1380. [CrossRef]

52. Jantunen, A.; Tarkiainen, A.; Chari, S.; Oghazi, P. Dynamic capabilities, operational changes, and performance outcomes in the media industry. J. Bus. Res. 2018, 89, 251-257. [CrossRef]

53. Zikmund, W.G.; Babin, B.J.; Carr, J.C.; Griffin, M. Business Research Methods, 9th ed.; Cengage Learning: Boston, MA, USA, 2013. 
54. Churchill, G.A., Jr. A paradigm for developing better measures of marketing constructs. J. Mark. Res. 1979, 16, 64-73. [CrossRef]

55. Ambulkar, S.; Blackhurst, J.; Grawe, S. Firm's resilience to supply chain disruptions: Scale development and empirical examination. J. Oper. Manag. 2015, 33, 111-122. [CrossRef]

56. Hair, J.F.; Black, W.C.; Babin, B.J.; Anderson, R.E.; Tatham, R.L. Multivariate Data Analysis; Prentice Hall: Upper Saddle River, NJ, USA, 1998.

57. Muthén, L.K.; Muthén, B. Mplus User's Guide; Muthén \& Muthén: Los Angeles, CA, USA, 2014.

58. Henseler, J.; Ringle, C.M.; Sarstedt, M. A new criterion for assessing discriminant validity in variance-based structural equation modeling. J. Acad. Mark. Sci. 2015, 43, 115-135. [CrossRef]

59. Bagozzi, R.P.; Yi, Y. Multitrait-multimethod matrices in consumer research. J. Consum. Res. 1991, 17, 426-439. [CrossRef]

60. Zhu, H.; Lyu, Y.; Deng, X.; et al. Workplace ostracism and proactive customer service performance: A conservation of resources perspective. Int. J. Hosp. Manag. 2017, 64, 62-72. [CrossRef]

61. Hair, J.; Hult, G.; Ringle, C.; Sarstedt, M. A Primer on Partial Least Squares Structural Equation Modelling (PLS-SEM); Sage: Los Angeles, CA, USA, 2014.

62. Byrne, B.M. Structural Equation Modeling with EQS and EQS/Windows: Basic Concepts, Applications, and Programming; Sage: Thousand Oaks, CA, USA, 1994.

63. Seibert, S.E.; Kraimer, M.L.; Liden, R.C. A social capital theory of career success. Acad. Manag. J. 2001, 44, 219-237.

64. Cortina, J.M.; Chen, G.; Dunlap, W.P. Testing interaction effects in LISREL: Examination and illustration of available procedures. Organ. Res. Methods 2001, 4, 324-360. [CrossRef]

65. Saris, W.E.; Batista-Foguet, J.M.; Coenders, G. Selection of indicators for the Interaction term in structural equation models with interaction. Qual. Quant. 2007, 41, 55-72. [CrossRef]

66. Bentler, P.M.; Bonnet, D.C. Significance tests and goodness of fit in the analysis of covariance structures. Psychol. Bull. 1980, 88, 588-606. [CrossRef]

67. Aiken, L.S.; West, S.G. Multiple Regression: Testing and Interpreting Interactions; Sage: Thousand Oaks, CA, USA, 1991.

68. Edwards, J.R.; Lambert, L.S. Methods for integrating moderation and mediation: A general analytic framework using moderated path analysis. Psychol. Methods 2007, 12, 1-22. [CrossRef] [PubMed]

69. Ye, S.; Xiao, H.; Zhou, L. Commodification and perceived authenticity in commercial homes. Ann. Tour. Res. 2018, 71, 39-53. [CrossRef]

70. Dai, S.; Xu, H. A system dynamics approach to explore sustainable policies for Xidi, the world heritage village. Curr. Issues Tour. 2012, 15, 441-459.

71. Chrzan, J. Slow food: What, why, and to where? Food Cult. Soc. 2004, 7, 117-132. [CrossRef]

72. Simonetti, L. The ideology of slow food. J. Eur. Stud. 2012, 42, 168-189. [CrossRef] 